\title{
Life, Death, and the State
}

\section{On the Latest Junctions of the Political and the Sacred}

Svyatoslav I. Kaspe

\author{
Svyatoslav I. Kaspe, DSc (Political Science) \\ National Research University-Higher School of Economics, Moscow, Russia \\ School of Politics and Governance \\ Professor; \\ Politeia Journal \\ Editor-in-Chief \\ SPIN RSCI: $3307-5864$ \\ ORCID: 0000-0001-6746-510X \\ ResearcherID: K-3951-2015 \\ Scopus AuthorID: 56162811000 \\ E-mail: kaspe@politeia.ru \\ Address: Office M20-423, 20 Myasnitskaya Str., Moscow 101000, Russia \\ DOI: $10.31278 / 1810-6374-2021-19-3-174-204$
}

\section{Abstract}

The author postulates that the recently widely discussed alternatives to the state as a political form and to specific states-empire, terrorist networks, transnational corporations, and international organizations-shared the qualities of transboundariness and extraterritoriality, while the state's substantive feature had always been territoriality which helped it survive many conflicts. The first political effect of the COVID-19 pandemic, which is also global and transnational, is the revitalization of the state and especially its territorial dimension, that is, its right to establish and strengthen external and internal borders. Yet another, more important political effect of the pandemic is that the state has regained its sacred (in the sociological sense of the word) status and the role of the "salvation operator," which it had had primordially and which temporarily receded into the background 
due to the widespread perception of the state exclusively as a "service structure." The author believes that this return will significantly affect the course and outcome of another emerging conflict-between the state and digital platforms that are rapidly acquiring all the features of the sacred, in Durkheim's interpretation of the term. The author concludes that it is the new junctions between the political and the sacred that will determine the further development of the world and the state.

Keywords: the state, non-state actors, empire, terrorist networks, transnational corporations, international organizations, digital platforms.

\author{
"Salus ${ }^{1}$ populi suprema lex esto."
} Cicero, De Legibus (III, III:VIII)

\title{
THE STATE IS STILL OUT THERE
}

In recent decades, the state has shown much more resilience than was expected of it-as a political form, that is, a certain combination of institutions, rules, and practices of "shaping and sharing of power" (Lasswell and Kaplan, 1950, p. XIV), and as a metaphor generated by this combination and reproducing it, and playing a "role simultaneously descriptive, ascriptive and prescriptive" (Kaspe, 2012, p. 13). ${ }^{2}$ Individual states, of course, have had a hard time, and some of them have turned into total nonentities, with very few chances for a comeback. But the state per se is still here, perhaps because its inevitable decline was predicted mainly by intellectuals, philosophers, and scholars (see, for example, Creveld 1999; Aronowitz and Bratsis, 2002; Spruyt, 2002). The functionaries of the real state apparatuses had a different opinion on this matter. More importantly, a majority of ordinary citizens of states

\footnotetext{
1 "Salus" is not only "the good," as it is usually translated, but also "safety," "health," and "salvation." The first scholar to draw attention to the broad meaning of this word and the entire formula in relation to the current situation is, perhaps, Alexander F. Filippov.

2 I should specify right away that I proceed from the assumption that this political form and this metaphor are exclusively of Western origin. So, it would be terminologically and historically incorrect to call truly original non-Western political forms states, while all other non-Western states are various replicas of the phenomenon that emerged in the West in the second half of the second millennium of the Christian era. A detailed substantiation of this point of view is beyond the limits of this article.
} 
adhered to a different opinion, too. They were in no hurry to swap a bird in the hand for two in the bush-even though the bird in the hand certainly deserved serious criticism.

The rivals of the state, capable of undermining its status as the conventional standard of political organization, do exist. The most often mentioned among them are:

- empire as a global, universal superstructure of the West's political domination, integrated in more important respects and diversified in less important ones, U.S.-centered but not confined to the United States. "Its goal of translating imperial rulings into local languages, harmonizing them with local traditions and overseeing their observance (the task of local self-government on a national scale) is entrusted to the elites of individual countries-on the one hand, connected by the umbilical cord with their mother communities, and on the other hand, more or less tightly integrated into the global establishment" (Kaspe, 2007, p. 267. See also: Hardt and Negri, 2000; Lundestad 2003; Ferguson 2004). But presenting the empire and the state as mutually exclusive alternatives is incorrect not because the empire of the West as a whole and the United States as its center are now experiencing big problems. In fact, any imperial project (all Romes - those in the East from the First to the Third, in the West from Charlemagne through Otto the Great to Charles V and Franz Joseph I, with a parallel branch to Zweites and Drittes Reich, as well as all other replicas, including the British and French ones) is a long endeavor going through numerous crises, disasters, remissions, and restorations. The modern empire of the West may rise again-the prophecies about the "decline" or "death of the West" have long turned into dead commodities. They are incorrect because an empire is a system of "indirect rule" (Tilly 1997), where entities of different ranks and forms - cities, realms, kingdoms, chiefdoms ... and states-are subordinated to the imperial center on individually selected terms. The precedents are well known. So, nothing will prevent states from remaining modular structural elements of the global empire and, as before, from setting "a framework, or kind of 'reference grid, for all political processes to evolve in" (Melville et al., 2010, p. 7). 
- terrorist networks, primarily Islamist: Al-Qaeda, Islamic State, etc. (nomen illis legio). In contrast to the empire, they are a real alternative and a direct challenge to the state, especially if we bear in mind that the very same Islamic State is not a state at all. It is an extraterritorial and transnational political form so named by misunderstanding and arranged on fundamentally different grounds (see Kuznetsov 2015; Kaspe 2018a, p. 18; Golunov 2020). According to Sheldon Wolin's paradoxical definition, it is "a formless form" (Wolin, 2004, pp. 559560). However, terrorist networks, even those that managed to inflict quite sensitive blows on the state (some states), are now mostly in a semi-collapsed condition. The countries that brought them to this condition and keep them in it have demonstrated (for example, in and around Syria) an unexpected ability to put aside disagreements for the sake of defeating a common enemy, albeit only partially and temporarily. And the enemy is being eliminated by and large, although it retains some residual vitality.

- transnational corporations. They have amassed truly colossal material resources (comparable to some countries' national budgets and in many cases exceeding them) and no less impressive human potential (the public sector rarely withstands competition with the private sector in attracting the best workers and, especially, brains). Also, they show a remarkable ability to maneuver between national jurisdictions, evade their claims and lobby for their own-not only economic, but also political-interests. Yet transnational corporations have failed to deprive states of the right and the ability to set the rules of the game. And they could hardly succeed in doing so: the regulatory and note-issuing powers remain with the states, while block-chain currencies either are still exotic or adopted by the states themselves. Tax havens and banking secrecy are under ever-increasing state pressure, and even private military companies, which seemingly dilute state monopoly on legitimate violence, work mainly on orders from the states, not corporations. None of them has come close to the political might United Fruit or Standard Oil once possessed. (After all, Bernard Madoff died in a government prison, but no statesman has passed away in a corporate one.) Naturally, the tug-of-war between 
corporations and states continues. Quite indicative was the recent attempt by Delta Airlines, Coca-Cola, and MLB to openly challenge electoral legislation changes in the state of Georgia, and the angry rebuke from the Republicans' leader in the Senate, Mitch McConnell: "Parts of the private sector keep dabbling in behaving like a woke parallel government. Corporations will invite serious consequences, if they become a vehicle for far-left mobs to hijack our country from outside the constitutional order" (McConnell, 2021). "My warning to corporate America is to stay out of politics" (Armus, 2021). And this statement is hardly a partisan position only. There are no signs in sight that states may suddenly surrender in this competition.

- international organizations, global (primarily the UN and all its satellite structures) and regional (primarily the EU), as well as transnational NGOs (Greenpeace, Amnesty International, Médecins Sans Frontières, etc.) They have regularly been named as a real threat to the state as a political form-often with a considerable degree of paranoia, especially when the Bilderberg Club and its analogues were included in the same list. But even if we ignore the conspiracy theories about a mysterious "world government" and take into account only serious works of an analytical, predictive and/or proactive nature (Heater, 1996; Wendt, 2003; Etzioni, 2004; McClintock, 2010), we still have to admit that the program of stateless and, moreover, nonimperial cosmopolitanism has failed. Neither the fears it generated, nor the hopes placed on it have come true, firstly, because the cosmopolitan forces, either individually or collectively, failed to accumulate moral authority and value legitimacy sufficient to compete with the state as a political form and with states as active actors; secondly, because the elementary organizational effectiveness of cosmopolitan forces proved to be scanty in comparison with the scope of the fears and hopes they generated. This is an utter failure.

\section{INTERIM}

A common feature of all named rivals of the state is their global, at least transnational, transboundary, and extraterritorial nature. This is no coincidence-after all, territoriality is a specific substantive feature 
of the state as a political form (Tilly, 1975, p. 27; Opello and Rosow, 1999, p. 37; Badie, 1987, 1995). True, as Jurgen Habermas (1996, p. 291) once remarked with grumpy displeasure, the state "almost neurotically watches its borders." But the condemnation tone is inappropriate here-after all, the state arose under the "Imperator in regno suo" slogan (Kantorowicz, 1997, pp. 49-66; Skinner, 1978, p. 11) by the means of and at the cost of abandoning universalist claims in exchange for complete and unconditional power inside a closed, fenced-both physically and symbolically-segment of space. In implementing this program, the opponents of the state were universalist, ecumenical forces potentially laying claim to the entire ecumene-the Empire and the Church (for details see Kaspe, 2007, pp. 120-154). They lost while the state won. Therefore, it is not surprising that "shape-memory" prompts the state to take care of... not just its own boundaries, but its own raison d'être, that is, raison d'etat.

\section{COVID-19: WHEN THE STATE MEETS DEATH, AGAIN}

Many were quick to note that the revitalization of the state (some individual states suffered hard, but the form per se has strengthened) was the main political effect of the COVID-19 pandemic (Caron, 2020; Delanty, 2021; also see a series of articles in Russia in Global Affairs, No. 2, 2020 and in Rossiya v globalnoi politike, No. 3 and 5, 2020). Here, of course, a significant role was played by the rational logic of individual and collective actors, who pinned their expectations and demands on the state, simply because there was nothing else to rely on. The bon mot attributed to Henry Kissinger: "Who do I call if I want to speak to Europe?" has not lost its relevance, which not so long ago (by Kissinger's standards) he confirmed himself (Sobczyk, 2012). The same can be said about the UN, the WHO and other institutions that are "terribly distant from the people." The state is somewhat closer.

But there are other, more profound political consequences of the pandemic. The most visible and tangible (both in literal terms) is the re-legitimation of borders, which many ardently and passionately urged to replace with bridges. Remarkably, the proponents meant not only interstate borders, which at a certain point looked almost eliminated 
in Europe, but also internal ones-cf. multiple selective lockdowns in certain regions, provinces, and cities-and even certain kinds of public spaces (museums, theaters, stadiums, restaurants, etc.). As a result, the term 'ghettoization' now sounds relevant, while the term 'open society' looks like a mockery. As for the freedom of movement that was promised by nearly all constitutions, vae victis-woe to the vanquished! (For a broader territorial aspect of the pandemic, see OECD 2020). This is how the nature of state power manifested itself again. After all, it was not a matter of drawing some dividing line between sheep and goats, but of the very right of the state to separate some from the others, to draw, defend and, most importantly, close any borders, including those between public and private life (cf. digital passes, forced testing, social monitoring, and isolation). The state has restored its power over the physical and symbolic space, and through it over the bodies and souls of the people inhabiting this space. The pretty much forgotten right of the state to such power remained in its arsenal all along. Like a regalia, a palladium, and a fetish.

Something like this, apparently, had been ripening even before the pandemic. Otherwise, it is hard to explain the irrational phobia of "foreign interference" in electoral and other political processes, which swept some countries several years ago (regardless of how liberally and democratically they are governed). This phobia increasingly looks like neurosis. In fact, until recently it was believed that states united to form an "international community" in order to influence each other and participate in a joint movement towards the common good. To exercise influence primarily in terms of promoting the values adopted and listed, for example, in the 1948 Universal Declaration of Human Rights and in hundreds of other documents. It was for this purpose that special institutions were created not only for international, but also foreign monitoring of elections. Eugen Rosenstock-Huessy had formulated this attitude with the utmost clarity ten years (and what years!) before the Universal Declaration: "No state is morally sovereign" (Rosenstock-Huessy, 1938, p. 409). Further, however, there followed an essential clarification: "That is the difference between a Christian and pagan government” (Ibid.). Well; there is, after all, a quite convincing 
point of view, according to which "secularization becomes possible as a result of a kind of... movement within the limits of Christian culture"precisely and only within it, by virtue of its own specific properties, one of which is the fundamental possibility of secularization "not as a special and temporary condition, existing due to oversight or delusion, but as a reproductive situation" (Salmin, 2009, pp. 155-156). No state in the West, however secularized, is capable of ridding itself of the imprint left by its origin rooted in the Christian view of the world, the human being, and earthly power. The same is true of their organized coalitions and alliances.

It is useless to deny that the genealogy of the Universal Declaration is also traced back there, which the American Anthropological Association critically but unsuccessfully pointed out when the document was being drafted (Statement, 1947; see Engle, 2001 for interesting details). On the other hand, what Rosenstock-Huessy obscurely called "paganism" is by no means brought in from outside. It is also part of the internally controversial and conflicting Western tradition, in which at a certain historical moment "the laws of the state must become independent of subjective content, including religious tenets or legal justifications and propriety, and should be accorded validity only as the result of the positive determination of the state's decision-making apparatus in the form of command norms. Auctoritas ... non veritas" (Schmitt, 1996, p. 44). The surge of neurotical, and sometimes maniacal, concern of states about protecting their sovereignty from any external influences, real or imaginary, is a sure mark that the pendulum of the state's political consciousness (and sub-consciousness), having gone in one direction, has now swung in the other-if not literally pagan, then at least nonChristian and even partially counter-Christian simply because other gods are worshiped on this side. The pandemic has merely stimulated and explicated this reverse movement.

However, there is still a less obvious but important factor that can entail significant consequences. The COVID-19 pandemic has confronted humanity with the question of life and death. This situation is by no means unique, but it is a long time since the alternatives looked as stark as they do today. In any case, speculations like "the publics 
of advanced industrial societies experienced unprecedented levels of existential security," something Ronald Inglehart insisted on for decades (Inglehart, 2018, p. 2), dubious all along, now sound somewhat indecent. In the absence of other candidates, the state has assumed-more or less reluctantly but certainly without enthusiasm-the responsibility for solving the question of life and death. Thereby the state as a political form has regained its identity and returned to its original domain, because it is precisely the power over life and death that it once sought to acquire and eventually acquired. This is how it gained its power and glory (or disgrace, depending on how you look at).

Naturally, any political form deals with life and death. This is the essence of the political form per se. Niccolo Machiavelli in his day recognized that "war... is the sole art that belongs to him who rules" (Machiavelli, 1908, p. 117). Karl Schmitt (who was many times and mostly deservedly condemned, but never proved wrong in essence) wrote about the same when he deduced the political from "the real possibility of physical killing" (Schmitt, 2007, p. 33) and argued that "by virtue of this power over the physical life of men, the political community transcends all other associations or societies" (Ibid., p. 47). While making a reservation "it is by no means as though the political signifies nothing but devastating war and every political deed a military action" (Ibid., P. 47), Schmitt nevertheless insisted: "War... is the leading presupposition which determines in a characteristic way human action and thinking and thereby creates a specifically political behavior" (Ibid., p. 34).

Yet the state stands out in this respect among other political forms. After all, Max Weber, in his speculations about the state's monopoly on legitimate violence (which ultimately results precisely in the cessation of life and the infliction of death, but only as a last resort; in order to maintain a domination-submission relationship, usually less radical violent actions and in most cases even a latent possibility of such actions would be enough), did not refer to "political organizations" in general (that is, organizations whose stability and significance are ensured "by the threat and application of physical force on the part of the administrative staff" (Weber, 1978, p. 54). He referred to the 
modern state: "Today the relation between the state and violence is an especially intimate one $\langle\ldots\rangle$ Specifically, at the present time, the right to use physical force is ascribed to other institutions or to individuals only to the extent to which the state permits it" (Weber, 1946, pp. 3-4). This double emphasis on a certain historical constellation is definitely not accidental.

Generally speaking, any political power enters into the area which Edward Shils called "serious things", i.e., things of "transcendental importance" "thought to be fundamental, that is, which affect the fate of human beings on Earth, in life and in death" (Shils, 1988, p. 251). And not only through the violent command of the latter (in another work, listing "serious things," Shils adds "justice" and "order" to life and death (Shils, 1997, p. 171) This is the area of the maximum existential tension in which the problems of truth, meaning, suffering and salvation are solved. To put it bluntly, it is the realm of the sacred: "Ultimate things are sacred things" (Shils, 1975, p. 154).

That the political and the sacred are linked not occasionally and accidentally, but causally and substantively is a commonplace idea, a truism. Power (at least genuine power) produces "institutional charisma" (Shils, 1975, p. 266) in the original (and Weberian) sense of the word: "It is a sign, not of popular appeal or inventive craziness, but of being near the heart of things" (Geertz, 1977, p. 151). That is why it is capable not only of ordinary violent and/or redistributive operations (this is something that the unum magnum latrocinium, the "great robbery" according to Augustine of Hippo (De Civitate Dei IV, 4), can cope with pretty well), but also of "the construction and attainment of meaningful social order which is closely related... to the realm of the sacred" (Eisenstadt, 1988, p. 96). "Authority... arouses sentiments of sacredness. Sacredness by its nature is authoritative" (Shils, 1975, p. 5). "Earthly power, as well as transcendent power, can protect or damage; it has the power to end life or to continue it... It is involved in processes, as vital as those at the disposal of priests and magicians" (Ibid., p. 264).

However, in terms of its relationship with the sacred, the state is something special that distinguishes it from other political forms. 
The state has been present on the "salvation markets" (a formula that is logically deduced from the research language of rational choice theories willingly operating with the concepts of "religious markets" and "salvation goods" - see, for example, Young, 1997; Jelen, 2002; Stolz, 2008a) since its appearance in the historical arena. It has captured a huge share of these markets in fierce competition with the already mentioned universalist rivals-the Ecumenical Church and the Holy (sic!) Roman Empire. The Empire and, over time, the monarchies of the Habsburgs and the Hohenzollerns that grew out of it were eliminated. The Church was not, although great efforts were exerted to this end ("and the gates of hell shall not prevail against it" (Matthew 16:18)). However, in the process of its consolidation, the state borrowed a great deal from the Church-not only legal, administrative, financial and other techniques (see Berman, 2009, pp. 85-119, 165-254), but most importantly, the claim to be the operator of the salvation market. Moreover, the one that would perform the roles of the regulator, general customer and general contractor delegating certain segments of this market and/or types of services to subcontractors, whose modest role is now assigned to traditional "hierocratic organizations" (according to Weber), to say the least. At the most, the state takes on this function, too, and performs it monopolistically.

This intention was clearly indicated by Jean-Jacques Rousseau in the penultimate chapter of his treatise The Social Contract: "Whoever dares to say: 'Outside the Church is no salvation' ought to be driven from the State, unless the State is the Church, and the prince the pontiff"(Rousseau, 1923, p. 122). That is why "all significant concepts of the modern theory of the state are secularized theological concepts not only because of their historical development... but also because of their systematic structure" (Schmitt, 2005, p. 36). "Historical development" is more important here than the "systematic structure" that Schmitt himself put the emphasis on-the formal similarity could have been considered accidental, but this is a direct genetic relationship confirmed by numerous facts and tests. It was also noted, for example, by Louis Dumont: "The modern State is not in continuity with other political forms: it is a transformed Church" (Dumont, 1985, p. 112). 
Parallel to the state political form, a matching model of collective and personal identity is constructed, "in which the 'last' community will be the state, not a kindred group, class or confession. More precisely, the state must become all of them at once" (Balibar, 1992, p. 157). "Confession" rightfully rounds out this list—the state claims to be not only the highest representation and substitute for clan intimacy and socioeconomic solidarity, but also an object of faith. And it requires that faith in it be confessed. Perhaps the most powerful sacred aspect of the state is manifested in its tendency to demand human sacrifices and the ability to receive them-in the way expressed in the "Dying for the Motherland" formula studied by Ernst Kantorowicz (1951), and in other ways. It is the "theological discourse that has provided models for the idealization of the nation and the sacralization of the state, which make it possible for a bond of sacrifice to be created between individuals, and for the stamp of 'truth' and 'law' to be conferred upon the rules of the legal system" (Balibar, 1990, p. 348).

Of course, the salvation that is offered and promoted by the state differs from the ecclesiastical, Christian and, in general, religious one. It is mundane and remains so even when the state to some extent manages "to unite the dead, the living and the yet unborn in a single community of fate" through propaganda and the imposition of a "secular version of immortality" (Smith, 2003, p. 140). "Even a transcended state-and they all try to transcend themselves in one way or another-remains an Earthly City. Even Leviathan remains a mortal god" (Kaspe, 2018a, p. 11). Yes, a god sui generis; and still, exactly according to Thomas Hobbes, a "mortal" one (Leviathan II, XVII), i.e., belonging to "this world" (for the transcendence of the state in greater detail see Kaspe, 2007, pp. 155-202). However, on the markets of the salvation in secularized societies-and secularization alone does not abolish them (Koenker, 1965; Bacon, Dossett and Knowles, 2015)—this commodity is quite in demand.

The mission of salvation from COVID-19 that the states have assumed volens nolens firmly pushes them back into the realm of the sacred, from where some of them (primarily a majority of the so-called "developed" ones) have almost retreated, having reconciled 
with the fashionable opinion of themselves as service structures with no will and power of their own. Humanity is attacked by an invisible evil, and the nature, origin and mechanisms of this evil are vague. Science is unable to say anything intelligible and reassuring about this (at least, in a language understandable to the everyman). The countermeasures it offers do not work everywhere, all the time, and for all. The criteria dividing people into those who are destined to survive and those doomed to die are unknown. The threat is existential and irrational; salvation is not guaranteed to anyone. The attitude to this evil naturally becomes a matter of faith, not knowledge. Non-believers are stigmatized as 'COVID-dissenters' (a term of religious origin). Dissenters react in a mirror-like fashion, accusing their opponents of blindly trusting any messages coming from official sources (cf. the caustic word 'COVID-frenzy' with the same connotations). States, as one would expect, mostly stand on the side of the orthodox majority, against heretics and unbelievers (the rare exceptions stemming from the individual psychic features of certain heads of state like Tanzania's President John Magufuli, who denied the very existence of the coronavirus and, in the end, died from it, do not change the general picture). Government measures to fight the incomprehensible evil are also often irrational and vary from country to country (the obligatory wearing of gloves, checking the temperature of visitors in public places, curfews, washing of sidewalks and roadways with chemicals, lockdowns for elderly people, treatment with hydroxychloroquine, transfusion of recovered COVID patients' blood plasma, etc.)

The salvation from the evil being sought by billions of human beings is, of course, not transcendental and spiritual, but earthly and bodily as is the evil itself. One may also encounter this sort of soteriology: "Deprivation, misfortune and suffering lead the individual to search for compensation; he or she may look for a salvation good which promises release from misfortune, deliverance from evil, or bodily healing in the near or distant future" (Stolz, 2008b, p. 61). Demand creates supply. States fight to save "bare life," according to Giorgio Agamben (see Chandler, 2020), because this is what is required of them and because they have nothing else to offer. But even this struggle is colored in 
(quasi)religious tones. Neglect of lockdown restrictions, let alone their utter rejection, is qualified as a moral crime. That is why the disrupters are punished by the state with repression to the fullest extent... not even by the law (these restrictions have no legal basis to rely on), but by a state of exception, almost never declared de jure, but introduced de facto (see Filippov, 2020a, 2020b). The bulk of the population grumbles but agrees to toe the line. However, individual fanatics voluntarily join the crusade against heretics, without waiting for the authorities to intervene (cases of spontaneous beatings of offenders of facemask rules in public transport and in supermarkets by angry passengers and shoppers are not rare). ${ }^{3}$ Simultaneously, the state dictates, without hesitation, its ideas of what kind of salvation is really important here and now for those who have a fundamentally different opinion on this matter-hierocratic organizations (both their leaders and rank-and-file members). Access to churches, mosques, synagogues, and temples is blocked; participation in rituals and sacraments, especially collective ones, is obstructed to the maximum extent; and resistance is suppressed by force-from police dispersals of ultra-Orthodox Judaic (Haredi) gatherings and processions in Israel to police intrusion into a women's monastery in the Central Urals in Russia. This is not surprising-after all, the questioning of the state's right to be the supreme operator of salvation and to set the rules of the game on this market delegitimizes it in toto like very few other things can.

As many observers have already noted, the political effects of the pandemic confirm Schmitt's famous definition of sovereignty: "Sovereign is he who decides on the exception" (Schmitt, 2005, p. 5). Remarkably enough, the sovereign is not always the one from whom this quality is expected ex officio. For example, in Russia in the spring of 2020, extraordinary anti-COVID measures were developed, introduced, and implemented across the country not so much by the federal authorities, as by Moscow Mayor Sergei Sobyanin, who had gone far beyond his powers to take this responsibility at his own initiative and without notice. Some astute (or snide) observers were

A similar observation is presented by British physician David Salkin (2020) in an article entitled Covid Is the New Religion, and That Is the Gospel Truth. 
quick to dub him a "sovereign." Many governors and mayors in the United States acted likewise-while President Donald Trump still professed coronascepticism (however, sovereignty in the realities of the United States is very different from that both in Russia and Europe). But these particulars are of secondary importance. What is really significant (and undeservedly recalled very rarely) is how Schmitt's treatise beginning with this definition is entitled: Political Theology. The current events are taking place precisely in this space and must be interpreted with the help of this conceptual apparatus. Closely related to it is the Terror Management Theory combining anthropology, psychology and sociology, and developed back in the 1980s (Greenberg, Pyszczynski and Solomon 1986; Routledge and Vess, 2019). These days it is getting a second wind (hopefully, this does not sound too cynical in relation to the coronavirus pandemic (Pyszczynski et al., 2020; Parenkov and Petrov, 2020)).

In the life of political societies, not only concepts and models originating from the "theological discourse" but also patterns of practical action, isomorphic to them, become distinguishable again. States direct and redirect the flows of specific "blessed sacraments" (masks, oxygen, lung ventilators, vaccines, etc.), thereby nourishing the salvation-thirsty flock with these material attributes of grace. In the regions of the world hit the hardest by this evil, detachments of valiant medical crusaders, heavily armed with the same gifts hurry to the rescue beneath the shade of the Red Cross. Before our very eyes, a new secular cult of the righteous, martyrs and saints-doctors and orderlies from the "red zones" of COVID hospitals-is taking shape. And so on and so forth. A common response to the pandemic now is "The world will never be the same." But this is not true. The world has already been in a situation like this many times. Humanity, especially its Western part, has simply forgotten what it is like to live (and die) during a holy war. Welcome back to the real world.

\section{THE HIDDEN MENACE: DIGITAL VS POLITICAL}

Before moving on to conclusions and tentative forecasts, it is worth putting forward one more assumption. Most likely, many battles of 
another war, which the state is already waging, will unfold in the same realm between the political and the sacred. It is a war with another global, transnational, cross-border and extraterritorial adversarydigital platforms (at the top of any such list one finds Microsoft, Google, Facebook, and Twitter, but this is merely the tip of the iceberg, steadily growing from below), whose activity in this vaguely demarcated and poorly protected area is growing by leaps and bounds. This is happening because their modus operandi contains more and more of what is hard to describe without referring to the concept of the sacred.

My further statements are somewhat exaggerated, some of them indicate tendencies that have not fully ripened yet. But all of them are already taking place in one way or another right now. Digital platforms are everywhere and nowhere-they are rapidly losing any specific spatial localization and are drifting into "clouds" (sic!). They are omnipresent, omniscient, and omnipotent. At the same time, it is getting less and less clear, even for the fathers of self-learning neural networks, how exactly they work and what happens at their deep levels. The algorithms of digital platforms allegedly (and perhaps honestly at first) were aimed at taking into account the interests, preferences, social connections, tastes, and values of end users to the maximum degree, but in reality they change and mold mentality, psyche and soul, imposing some opportunities and excluding others, exactly as was predicted by Clive S. Lewis in The Abolition of Man: "We shall in fact be the slaves and puppets of that to which we have given our souls." They monopolize entire areas of decision-making. Take, for instance, the stock exchange, banking and investment robots with their speed no human can compete against. And not only economic decisionsdigital platforms are pretty close to gaining power over life and death. Today specialists actively discuss the possibility of vesting the artificial intelligence of combat systems with the right to independently make irreversible, lethal choices - not only distinguishing between "friends" and "foes" ("friends" and "enemies," strictly according to Schmitt), but also destroying the latter. Roughly speaking, machines are ready to kill humans-all technical conditions are in place. Ethical considerations remain the sole deterrent, but this is an unreliable safeguard: ethics is 
usually inferior to efficiency, and everything that can be technically implemented will materialize sooner or later.

However, the elimination of a person does not necessarily imply or requires physical violence. Remarkable in this respect is the fact that digital platforms have become the main medium and tool for promoting the ideology and practices of "cancel culture," aimed precisely at erasing and destroying, if possible, all social projections and traces of a person, who for some reason is recognized to be no good for further presence in the civilization. Not just a digital doppelgänger, but a significant, albeit incorporeal, part of the personality immersed in the digital universe and dependent on what is happening in it. This is what people's life-worlds and realities have become now (although their multiple forms were described by Alfred Schütz (1945) back in the middle of last century). Moreover, decisions of this kind can be challenged and appealed against only in exceptional cases. There is no one to lodge protests with. The verdict is final and not subject to appeal. A long-term or permanent ban in social networks is reminiscent of the notorious euphemism of the Stalin era: "ten-year prison term without the right of correspondence." It spelled death.

The functioning of digital platforms looks like power, is described as power, and is perceived as power-which means it is power in its own right. It is the very same Shilsean power that "arouses sentiments of sacredness," and the same Shilsean sacred which is "authoritative by its nature." There is no mysticism or conspiracy here. That is, they may well be present, but not necessarily-just as they are not present, for example, in Dominic Johnson's hypothesis of "supernatural punishment" (Johnson and Krüger, 2004; Johnson, 2005, 2015, 2016; Fokin, 2019). While remaining a naturalistic and even biologizing hypothesis, it freely operates with the concept of the sacred. It "describes a supernatural agent as a supernatural authority, that is, an agent with absolute power, performing punitive functions for the common good of the community, an agent who is obeyed not due to direct coercion but for rational (sometimes unconscious) considerations $<\ldots>$ Authority can manifest itself both as a position and as a person, $<\ldots>$ a supernatural agent (= God) is an (or the ) 
authority, while his minister, a priest or worldly leader, endowed with authority "from above," is an agent in authority, holding the current position only as long as Holy God permits" (Fokin, 2020, p. 203). It is extremely unlikely that on Judgment Day, an abstract Skynet will become self-aware and begin to rule the world and people. It is much more likely that it will begin to rule the world and the people without realizing its identity in the human sense of the word. It looks like it is already beginning to do so.

The digital sacred in question is, in fact, the very familiar sacred according to Emile Durkheim. In order to see that the comparison is correct it is worth re-reading famous passages from The Elementary Forms of the Religious Life. It does not matter to which object the properties and qualities of the sacred (society as a whole) are attributed. What really matters is what these properties and qualities are. The digital sacred obviously possesses them.

"For to its members it is what a god is to his worshippers... a god is, first of all, a being whom men think of as superior to themselves, and upon whom they feel that they depend. Whether it be a conscious personality... or merely abstract forces... the worshipper, in the one case as in the other, believes himself held to certain manners of acting which are imposed upon him by the nature of the sacred principle with which he feels that he is in communion $<\ldots>$ [It] gives us the sensation of a perpetual dependence. Since it has a nature which is peculiar to itself and different from our individual nature, it pursues ends which are likewise special to it; but, as it cannot attain them except through our intermediacy, it imperiously demands our aid. It requires that, forgetful of our own interests, we make ourselves its servitors, and it submits us to every sort of inconvenience, privation and sacrifice, without which social life would be impossible. It is because of this that at every instant we are obliged to submit ourselves to rules of conduct and of thought which we have neither made nor desired, and which are sometimes even contrary to our most fundamental inclinations and instincts $<\ldots>$ We yield to its orders, it is not merely because it is strong enough to triumph over our resistance $\langle\ldots\rangle$ when the representation... is gifted with such a force that it automatically causes 
or inhibits actions, without regard for any consideration relative to their useful or injurious effects $<\ldots>$ The representations which express them within each of us have an intensity which no purely private states of consciousness could ever attain; for they have the strength of the innumerable individual representations which have served to form each of them... speaks through the mouths of those who affirm them in our presence; it is [it] whom we hear in hearing them; and the voice of all has an accent which that of one alone could never have. The very violence with which [it] reacts... against every attempted dissidence, contributes to strengthening its empire by manifesting the common conviction through this burst of ardor. In a word, when something is the object of such a state of opinion, the representation which each individual has of it gains a power of action from its origins and the conditions in which it was born, which even those feel who do not submit themselves to it $\langle\ldots\rangle$ [It] is not merely an authority upon whom we depend; it is a force upon which our strength relies. The man who has obeyed his god and who, for this reason, believes the god is with him, approaches the world with confidence and with the feeling of an increased energy $<\ldots>$ Collective force is not entirely outside of us; it does not act upon us wholly from without; but rather, since [it] cannot exist except in and through individual consciousnesses, this force must also penetrate us and organize itself within us; it thus becomes an integral part of our being and by that very fact this is elevated and magnified" (Durkheim, 1964, pp. 206-209).

At this point, we may stop; in fact, it would be possible to quote page after page, quite correctly extrapolating the classical descriptions of the sociological effects of interaction with the sacred to the modus vivendi and modus operandi of modern human beings in the world of digital platforms and social networks.

As they gain power and turn ipso facto into a political factor, digital platforms increasingly come into contact with states. Wherever they do, it starts sparking. China knows this very well. It has fenced off its digital space with the Great Firewall of China and has successfully filled the interior of this fortified perimeter with its own analogues of global platforms (but dissenters on both sides of the border still manage 
to make wormholes.) This is well known in Russia, which is engaged in sluggish border battles with global platforms by blocking some resources, slowing down others, and trying one way or another to lure their personal data servers and offices under its national jurisdiction. In other words, digital sovereignty is built according to the same templates as territorial sovereignty, but the results are doubtful, especially because the creation of alternative services, with rare exceptions like Yandex, leaves much to be desired. This is known in the United States, where the real terror, unleashed by key digital platforms against Trump and the Trumpists most likely had a significant impact on the results of the presidential election. This is also known in Australia, where the conflict between the authorities and Google and Facebook (Cherney, 2021) seems to have subsided, but its outcome is still anyone's guess. Most likely, over time, it will be known to everybody everywhere.

For the time being such skirmishes are largely directed and controlled by elites, both political and digital. States are deploying systems for monitoring, controlling, and manipulating human behavior, while non-state digital platforms are establishing their own ones. The parties have been calling each other names, like Big Brother, and exchanging symmetrical rebukes for encroachments on freedom. Illustrative in this respect are the statement by Microsoft President Brad Smith: "I'm constantly reminded of George Orwell's lessons in his book 1984. You know the fundamental story ... was about a government who could see everything that everyone did and hear everything that everyone said all the time. Well, that didn't come to pass in 1984, but if we're not careful that could come to pass in 2024" (BBC, 2021); and the lawsuit initiated by the authorities of the state of Arizona against Google, during which precisely the same accusations were made (McDonald-Evoy, 2021). ${ }^{4}$

That the matter is actually about intensified competition for power over consciousness, sub-consciousness, actions, and loyalty of ordinary citizens/users, and not about protecting them from such power is obvious. The real problem is that the elites-both the leaders of states

4 Remarkable in this publication is the definition of Google as "a tech behemoth." As is known, in medieval demonology Behemoth is one of the closest servants of the Satan. 
and the owners and top managers of digital platforms-will control the situation to a no bigger extent than the side effects and unintended consequences of the crusades were controlled by their initiators. Participants in the holy war behave unpredictably, and the problem is not only in excesses committed by mid-level executives, like the attack on Constantinople or spontaneous outbreaks of mass psychosis like the Children's Crusade (although both are quite likely and even inevitable). The real problem is that the modern holy war-between the sacred political and the sacred digital-will involve one more class of actors-"artificial agents, i.e., human-made technical devices and software that are capable of acting purposefully and making decisions independently" (Tomiltseva and Zheleznov, 2020, p. 90). (See also: Knight, 2019; Vaccari and Chadwick, 2020).

\section{THE STATE IN THE PURSUIT OF THE SACRED}

Thus, modern developments bring the sacred status and the role of salvation operators back to the states (the push-and-pull proportion in each individual case is specific and less important than the general trend). This can happen in different ways and with different efficiencyand, importantly, it is the efficiency and the ability to cope with such a role that will increasingly determine a state's competitiveness.

Those states that have developed stable models of joining the political and the sacred and where they are made legitimate (although, perhaps, remaining "rusty" due to long disuse) will enjoy a good head start. These are the states where such a model is embodied, above all, in the concept of "civil religion" - "a form of sacralization of a collective political entity that is not identified with the ideology of a particular political movement, affirms separation of Church and state" that "coexists with traditional religious institutions without identifying itself with any one particular religious confession, presenting itself as a common civic creed ... It recognizes broad autonomy for the individual with regard to the sanctified collectivity, and generally appeals to spontaneous consensus for observing the commandments of public ethics and the collective liturgy" (Gentile, 2005, p. 30). These are primarily the United States (Bellah, 1967; Crook, 2010; Gardella, 
2014) and Israel (Liebman and Don-Yihya, 1983; Lewin, 2013; DonYeihya 2018). Other countries often mentioned are Australia (Smith, 2003, p. 114; Gladwin 2016), and Chile (Cristi, 2001, pp. 165-186) (in addition to the classic work by Emilio Gentile (2006), see reviews by Cristi and Dawson 2007; Hvithamar, Warburg and Jacobsen, 2009).

Furthermore, those states that practice the model of "political religion"-"a form of the sacralization of politics of an exclusive and integralist character" - will also get a head start. This model "rejects coexistence with other political ideologies and movements, denies the autonomy of the individual with respect to the collective, prescribes the obligatory observance of its commandments and participation in its political cult, and sanctifies violence... It adopts a hostile attitude towards traditional institutionalized religions, seeking to eliminate them, or seeking to establish with them a relationship of symbiotic coexistence, in the sense that the political religion seeks to incorporate traditional religion within its own system of beliefs and myths, assigning it a subordinate and auxiliary role" (Gentile, 2005, p. 30). Indeed, North Korea and Turkmenistan have no operational global digital platforms... and, according to official figures, they do not have COVID-19, at all. In other words, it remains to be believed that the power of these extremely secluded states and the strength of their borders are good enough to prevent even non-cellular pathogens measuring 100-150 nanometers in diameter from entering their territory. Well, faith works miracles. (Although it is quite indicative that, regardless of faith, neither North Korea nor Turkmenistan is capable of securing true autarky for themselves: they maintain their specific ways of life (and death) exclusively through connections-carefully camouflaged from their populations - to external resources (specifically, to China in the former case and to the global oil market in the latter.)) Hardly any state will be able (or eager) to replicate these extreme options.

However, pure forms of both civil and political religions are rare, while inventing them from scratch or getting them on order is not an easy task. Therefore, the states that do not have such a head start but seek to strengthen the link with the sacred (and, accordingly, to build up their competitiveness), will have to experiment, combining 
in various ways elements of civil and political religions, trying to establish something average between these extremes, and producing all kinds of hybrids of a priori unknown viability. In fact, this is already happening: in Hungary under Viktor Orban, in Poland under Prawo i Sprawiedliwość, in Turkey under Recep Tayyip Erdogan, and in Russia under Vladimir Putin (Kaspe, 2018b). Pyotr Poroshenko's project-stalled but not closed-for autocephaly of the Ukrainian church also falls into the same category. Moreover, Emmanuel Macron's recent statements, which one would least expect from the President of France-the homeland of the Enlightenment, the cult of Reason and laicism, that is, one of the most radical versions of the secular state, are really amazing in this context. "Politics is mystical"; "I have always recognized the vertical, transcendental dimension [in politics]"; "Christ's dimension... I do not deny it, I do not claim it" (see a collection of such remarks and their expert analysis in: Malzac 2017). Yet the most significant is the following: "We intuitively share the feeling that the bond between the Church and the state has been damaged, and that both you and I need to repair it" (Macron, 2021).

\section{THIS IS NOT THE END}

All this is just the beginning. In any case, no factors or actors that can reverse the processes of (re)politicization of the sacred and (re) sacralization of the political are in sight. Because this is one and the same process-a stream that sweeps and carries all modern states, albeit with different strength and speed. "Launched in the middle of a rapid stream, we obstinately fix our eyes on the ruins which may still be described upon the shore we have left, while the current sweeps us along, and drives us backwards towards the gulf" (Tocqueville, 1838, pp. XIII-XIV). “The ruins" are the remnants of the secular world. "The gulf" is a post-secular world, in many respects different from the presecular one, but fundamentally very similar to it. The political and the sacred will again permeate each other and be transformed into each other, jointly determining the fate of human beings seeking salvation, including, and above all, their life and death. 


\section{References}

Armus, T., 2021. McConnell Says Companies Should Stay Out of PoliticsUnless They're Donating Money. The Washington Post, 7 April [online]. Available at: www.washingtonpost.com/nation/2021/04/07/mitch-mcconnell-georgiacitizens-united/ [Accessed 12 June 2021].

Aronowitz, S. and Bratsis P. (eds.), 2002. Paradigm Lost: State Theory Reconsidered. Minneapolis: Univ. of Minnesota Press.

Bacon, H., Dossett W. and Knowles, S. (eds.), 2015. Alternative Salvations: Engaging the Sacred and the Secular. L.: Bloomsbury.

Badie, B., 1987. Inventions et réinventions de l'Etat. In: Colas, D. and Emeri, C. (eds.) Droit, institutions et systemes politiques. Melanges en hommage à M. Duverger. P.: P.U.F., pp. 495-504.

Badie, B., 1995. La fin des territoires: essai sur le désordre international et sur l'utilité du respect. Paris: Fayard.

Balibar, E., 1990. The Nation Form: History and Ideology. Review (Fernand Braudel Center), 13(3), pp. 329-361.

Balibar, E., 1992. Nation, cité, empire (La problème de la forme politique bourgeoise). In: Balibar, E. (ed). Les frontières de la democratie. Paris: La Decouverte, pp.151-166.

BBC, 2021. Microsoft President: Orwell's 1984 Could Happen in 2024. $B B C$ - Panorama, 27 May [online]. Available at: www.bbc.com/news/ technology-57122120 [Accessed 12 June 2021].

Becker, E., 1997. The Denial of Death. N.Y.: Simon and Schuster.

Bellah, R.N., 1967. Civil Religion in America. Daedalus, 96(1), pp.1-21.

Berman, H.J., 2009. Law and Revolution: The Formation of the Western Legal Tradition. Cambridge (Mass.), L.: Harvard Univ. Press.

Caron, J.-F., 2020. A Sketch of the World After the COVID-19 Crisis: Essays on Political Authority, the Future of Globalization, and the Rise of China. s.l.: Palgrave Macmillan.

Chandler, D., 2020. The Coronavirus: Biopolitics and the Rise of 'Anthropocene Authoritarianism'. Russia in Global Affairs, 18(2) [online]. Available at: https://eng. globalaffairs.ru/articles/coronavirus-authoritarianism/ [Accessed 1 August 2021].

Cherney, M., 2021. Google Escalates Dispute with Australia by Threatening Search Shutdown. The Wall Street Journal, 22 January [online]. Available at: 
www.wsj.com/articles/google-escalates-dispute-with-australia-by-threateningsearch-shutdown-11611298523 [Accessed 12 June 2021].

Creveld, van M., 1999. The Rise and Decline of the State. Cambridge: Cambridge Univ. Press.

Cristi, M., 2001. From Civil to Political Religion: The Intersection of Culture, Religion and Politics. Waterloo: Wilfrid Laurier Univ. Press.

Cristi, M. and Dawson, L.L., 2007. Civil Religion in America and in Global Context. In: Beckford, J.A. and Demerath III, N.J. (eds.) The SAGE Handbook of the Sociology of Religion. Los Angeles: SAGE Publications, pp. 267-292.

Crook, T., 2010. Civil Religion and the History of Democratic Modernity: Probing the Limits of the Sacred and the Secular. Religion Compass, 4(6), pp. 376-387.

Delanty, J. (ed.), 2021. Pandemics, Politics, and Society: Critical Perspectives on the Covid-19 Crisis. Berlin, Boston: de Gruyter.

Don-Yeihya, E., 2018. Changes and Developments in Israeli Civil Religion: 1982-2017. Israel Studies, 23(3), pp. 189-196.

Dumont, L., 1985. A Modified View of Our Origins: The Christian Beginnings of Modern Individualism. In: Carrithers, M., Collins, S. and Lukes, S. (eds.) The Category of the Person: Anthropology, Philosophy, History. Cambridge: Cambridge University Press, pp. 93-122.

Durkheim, E., 1964. The Elementary Forms of the Religious Life. L.: Allen \& Unwin.

Eisenstadt, S.N., 1988. Transcendental Vision, Center Formation, and the Role of Intellectuals. In: Greenfeld, L. and Martin, M. (eds.) Center: Ideas and Institutions. Chicago, L.: The Univ. of Chicago Press, pp. 96-110.

Engle, K., 2001. From Skepticism to Embrace: Human Rights and the American Anthropological Association. Human Rights Quarterly, 23, pp. 536-560.

Etzioni, A., 2004. From Empire to Community: A New Approach to International Relations. N.Y.: Palgrave Macmillan.

Ferguson, N., 2004. Colossus: The Rise and Fall of the American Empire. N.Y.: Penguin Books.

Filippov, A.F., 2020a. The Pandemic: First Social Aftereffects and Prospects. Russia in Global Affairs, 18(2) [online]. Available at: https://eng.globalaffairs. ru/articles/pandemic-aftereffects/ [Accessed 1 August 2021]. 
Filippov, A.F., 2020b. Privychnye sposoby razlicheniya chistogo i nechistogo, opasnogo i bezopasnogo perestayut rabotat' [Ordinary Ways to Discriminate between Clear and Dirty, Dangerous and Safe No Longer Work]. Research Arts [online]. Available at: http://researcharts.ru/filippov-self-isolation [Accessed 1 August 2021].

Fokin, K.V., 2019. Gipoteza sverkhyestestvennogo nakazaniya: Kritichesky obzor [The Hypothesis of Supernatural Punishment: A Critical Overview]. Politeia, 1, pp. 60-80.

Fokin, K.V., 2020. Opyt izucheniya vlasti na interfeise politicheskogo i biologicheskogo [An Essay on Studying Power at the Interface of Politics and Biology]. Method, 10, pp. 196-211.

Gardella, P., 2014. American Civil Religion: What Americans Hold Sacred. N.Y.: Oxford Univ. Press.

Geertz, C., 1977. Centers, Kings and Charisma: Reflections on the Symbolics of Power. In: Ben-David, J. and Clarke, T.N. (eds.) Culture and Its Creators: Essays in Honor of Edward Shils. Chicago: The Univ. of Chicago Press, pp. 43-71.

Gentile, E., 2005. Political Religion: A Concept and Its Critics - A Critical Survey. Totalitarian Movements and Political Religions. Vol. 6, No. 1, pp. 19-32.

Gentile, E., 2006. Politics as Religion. Princeton: Princeton Univ. Press.

Gladwin, M., 2016. Anzac Day's Religious Custodians. In: Frame, T. (ed.) Anzac Day Then and Now. Sydney: New South Press, pp. 90-111.

Golunov, S.V., 2020. Terroristichesky "khalifat" kak kvazigosudarstvo: problema kontseptualizatsii [Terroristic "Caliphate" as a Quasi State: The Problem of Conceptualization]. Politeia, 2, pp. 87-103.

Greenberg, J., Pyszczynski, T. and Solomon, S., 1986. The Causes and Consequences of a Need for Self-Esteem: A Terror Management Theory. In: Baumeister, R.F. (ed.). Public Self and Private Self. N.Y.: Springer, pp.189-212.

Habermas, J., 1996. The European Nation-State: Its Achievements and Its Limits. On the Past and Future of Sovereignty and Citizenship. In: Balakrishnan, G. (ed.) Mapping the Nation. L., N.Y: Verso, pp. 281-294.

Hardt, M. and Negri, A., 2000. Empire. Cambridge (Mass.), L.: Harvard Univ. Press.

Heater, D., 1996. World Citizenship and Government: Cosmopolitan Ideas in the History of Western Political Thought. N.Y.: St. Martin's Press. 
Hvithamar, A., Warburg, M. and Jacobsen, B.A. (eds.), 2009. Holy Nations and Global Identities: Civil Religion, Nationalism, and Globalisation. Leiden, Boston: Brill.

Inglehart, R., 2018. Modernization, Existential Security, and Cultural Change. Reshaping Human Motivations and Society. In: Gelfand, M., Chiu, C. and Hong,Y. (eds.) Advances in Culture and Psychology, 7. N.Y.: Oxford Univ. Press, pp. 1-60.

Jelen, T.G. (ed.), 2002. Sacred Markets, Sacred Canopies: Essays on Religious Markets and Religious Pluralism. Lanham: Rowman and Littlefield.

Johnson, D. and Krüger, O., 2004. The Good of Wrath: Supernatural Punishment and the Evolution of Cooperation. Political Theology, 5(2), pp. 159-176.

Johnson, D., 2005. God's Punishment and Public Goods: A Test of the Supernatural Punishment Hypothesis in 186 World Cultures. Human Nature, 16(4), pp. 410-446.

Johnson, D., 2015. God Is Watching You: How the Fear of God Makes Us Human. N.Y.: Oxford Univ. Press.

Johnson, D., 2016. Hand of the Gods in Human Civilization. Nature, 530(7590), pp. 285-287.

Kantorowicz, E., 1951. Pro Patria Mori in Medieval Political Thought. The American Historical Review, 56(3), pp. 472-492.

Kantorowicz, E., 1997. The King's Two Bodies: A Study in Mediaeval Political Theology. Princeton: Princeton Univ. Press.

Kaspe, S.I., 2007. Tsentry i ierarkhii: prostransvennye metafory i zapadnaya politicheskaya forma [Centers and Hierarchies: Spatial Metaphors of Power and the Western Political Form]. Moscow: Moskovskaya shkola politicheskikh issledovaniy.

Kaspe, S.I., 2012. O ponyatii politicheskoi formy [On the Notion of Political Form]. Politeia, 4, pp. 5-28.

Kaspe, S.I., 2016. Politicheskaya forma i politicheskoye zlo [Political Form and Political Evil]. Moscow: Shkola grazhdanskogo prosvechsheniya.

Kaspe, S.I., 2018a. Chem torguyet Leviafan? Kriterii konkurentnosposobnosti gosudarstv na rynkakh spaseniya [What Does Leviathan Deal In? Evaluation Criteria for States' Competitiveness on "Salvation Markets"]. Politeia, 3, pp. 6-30. Kaspe, S.I., 2018b. Zagovor molchaniya: sopryazheniya sakralnogo i politicheskogo v diskursivnykh praktikakh sovremennoi Rossii [Conspiracy of 
Silence: Interfaces of Sacred and Political in the Discursive Practices of Modern Russia]. Sotsiologicheskoye obozrenie, 17(2), pp. 9-38.

Knight, W., 2019. Facebook, Google, Twitter Aren't Prepared for Presidential Deepfakes. MIT Technology Review [online]. Available at: https://www. technologyreview.com/2019/08/06/639/facebook-google-twitter-arentpreparedfor-presidential-deepfakes [Accessed 12 June 2021].

Koenker, E.B., 1965. Secular Salvations: The Rites and Symbols of Political Religions. Philadelphia: Fortress Press.

Kuznetsov, V.A., 2015. IG-alternativnaya gosudarstvennost'? Chem obyasniayetsa prityagatelnost' radikalov dlya zhitelei arabskogo Vostoka [ISISan Alternative Statehood? Why the Radicals Are Attractive to the Arabians in the Middle East]. Rossiya v globalnoi politike, 13(5), pp. 8-17.

Lasswell, H.D. and Kaplan, A., 1950. Power and Society: A Framework for Political Inquiry. New Haven, L.: Yale Univ. Press.

Lewin, E., 2013. The Clash of Civil Religions: A Paradigm for Understanding Israeli Politics. Jewish Political Studies Review, 25 (1/2), pp. 72-92.

Liebman, C.S. and Don-Yihya, E., 1983. Civil Religion in Israel: Traditional Judaism and Political Culture in the Jewish State. Berkeley, Los Angeles, L.: Univ. of California Press.

Lundestad, G., 2003. The United States and Western Europe Since 1945. From Empire by Invitation to Transatlantic Drift. Oxford: Oxford Univ. Press.

Machiavelli, N., 1908. The Prince. L.: J.M. Dent and Sons.

Malzac, M., 2017. Emmanuel Macron, un pragmatique aux allures de télévangéliste. La Croix, 9 May [online]. Available at: https://www.la-croix.com/ Religion/Catholicisme/France/Emmanuel-Macron-pragmatique-allures-televa ngeliste-2017-05-09-1200845692 [Accessed 12 June 2021].

Macron, E., 2021. Discours du Président de la République, Emmanuel Macron, à la Conférence des évêques de France au Collège des Bernardins. Élisée, April [online]. Available at: www.elysee.fr/emmanuel-macron/2018/04/09/discoursdu-president-de-la-republique-emmanuel-macron-a-la-conference-deseveques-de-france-au-college-des-bernardins [Accessed 12 June 2021].

McClintock, J., 2010. The Uniting of Nations: An Essay on Global Governance. Brussels: Peter Lang.

McConnell, M., 2021. McConnell: Corporations Shouldn't Fall for Absurd Disinformation on Voting Laws. Official Mitch McConnel website, 5 April 
[online]. Available at: www.republicanleader.senate.gov/newsroom/pressreleases/mcconnell-corporations-shouldnt-fall-for-absurd-disinformation-onvoting-laws [Accessed 12 June 2021].

McDonald-Evoy, J., 2021. Newly Unredacted Documents Show Google Shared Location with Other Apps and More. AZ Mirror, 24 May [online]. Available at: www.azmirror.com/2021/05/24/newly-unredacted-documents-show-googleshared-location-with-other-apps-and-more/ [Accessed 12 June 2021].

Melville A., Polunin Yu., Ilyin M., Mironyuk M., Timofeev I., Meleshkina E., and Vaslavskiy Y., 2010. Political Atlas of the Modern World. Oxford: WileyBlackwell.

OECD, 2020. The Territorial Impact of COVID-19: Managing the Crisis across Levels of Government. Available at: https://read.oecd-ilibrary.org/ view/?ref=128_128287-5agkkojaaa\&title=The-territorial-impact-of-covid-19managing-the-crisis-across-levels-of-government [Accessed 12 June 2021].

Opello, W.C. and Rosow J.S., 1999. The Nation-State and Global Order: A Historical Introduction to Contemporary Politics. Boulder: Lynne Rienner Publishers.

Parenkov, D.A. and Petrov, K.Ye., 2020. Koronavirus i politika: zaprosy i tsennosti $\mathrm{v}$ epokhu pandemii [The Coronavirus and Politics: Demands and Values in the Age of the Pandemic]. Mezhdunarodnaya analitika, 11(2), pp.109-121.

Pyszczynski, T., Lockett, M., Greenberg, J. and Solomon, S., 2020. Terror Management Theory and the COVID-19 Pandemic. Journal of Humanistic Psychology, March, 61(2) [online]. Available at: https://www.ncbi.nlm.nih.gov/ pmc/articles/PMC7498956/\#bibr25-0022167820959488 [Accessed 12 June 2021].

Rosenstock-Huessy, E., 1938. Out of Revolution. Autobiography of Western Man. N.Y.: William Morrow and Co.

Rousseau, J.-J., 1923. The Social Contract. In: Rousseau, J.-J. The Social Contract and Discourses. L.: Toronto: J.M. Dent and Sons, pp. 3-123.

Routledge, C. and Vess, M. (eds.), 2019. Handbook of Terror Management Theory. s.l.: Academic Press, 2019.

Salkin, D., 2020. Covid Is the New Religion, and That Is the Gospel Truth. The Pulse [online]. Available at: https://www.pulsetoday.co.uk/views/coronavirus/ covid-is-the-new-religion-and-that-is-the-gospel-truth/ [Accessed 12 June 2021]. 
Salmin, A.M., 2009. Sovremennaya demokratiya: ocherki stanovleniya I razvitiya [Modern Democracy: An Essay on Its Formation and Development]. Moscow: Forum.

Schmitt, C., 1996. The Leviathan in the State Theory of Thomas Hobbes: Meaning and Failure of a Political Symbol. Westport (Connecticut), L.: Greenwood Press. Schmitt, C., 2005. Political Theology: Four Chapters on the Concept of Sovereignty. Chicago, L.: The Univ. of Chicago Press.

Schmitt, C., 2007. The Concept of the Political. Chicago, L.: Chicago Univ. Press. Schütz, A., 1945. On Multiple Realities. Philosophy and Phenomenological Research, 5(4), pp. 533-576.

Shils, E., 1975. Center and Periphery: Essays in Macrosociology. Chicago: The Univ. of Chicago Press.

Shils, E., 1988. Center and Periphery: An Idea and Its Career, 1935-1987. In: Greenfeld, L. and Martin, M. (eds.). Center: Ideas and Institutions. Chicago, L.: The Univ. of Chicago Press, pp. 250-282.

Shils, E., 1997. Order of Learning: Essays on the Contemporary University. New Brunswick, L.: Transaction Publishers.

Skinner, Q., 1978. The Foundations of Modern Political Thought. Vol. 1. Cambridge; N.Y.: Cambridge Univ. Press.

Smith, A., 2003. Nationalism and Modernism: A Critical Survey of Recent Theories of Nations and Nationalism. L., N.Y.: Routledge.

Sobczyk, M, 2012. Kissinger Still Lacks a Number to Call Europe. The Wall Street Journal, 27 June [online]. Available at: https://www.wsj.com/articles/BLNEB-5698 [Accessed 12 June 2021].

Spruyt, H., 2002. The Origins, Development, and Possible Decline of the Modern State. Annual Review of Political Science, 5, pp. 127-149.

Statement on Human Rights, 1947. American Anthropologist, 49(4), pp. 539-543.

Stolz, J. (ed.), 2008a. Salvation Goods and Religious Markets: Theory and Applications. Bern, N.Y.: Peter Lang.

Stolz, J., 2008b. Salvation Goods and Religious Markets: Integrating Rational Choice and Weberian Perspectives. In: Stolz, J. (ed.) Salvation Goods and Religious Markets: Theory and Applications. Bern, N.Y.: Peter Lang, pp. 51-80. 
Tilly, C., 1975. Reflections on the History of European State-Making. In: Tilly, C. (ed.) The Formation of National States in Western Europe. Princeton: Princeton Univ. Press, pp. 3-83.

Tilly, C., 1997. How Empires End. In: Barkey, K. and Hagen, von M. (eds.) After Empire: Multiethnic Societies and Nation-Building. N.Y., L.: Westview Press, pp. 1-11.

Tocqueville, A. de, 1838. Democracy in America. N.Y.: G. Adlard.

Vaccari, C. and Chadwick, A., 2020. Deepfakes and Disinformation: Exploring the Impact of Synthetic Political Video on Deception, Uncertainty, and Trust in News. Social Media + Society, 6(1), pp. 1-13.

Weber, M., 1946. Politics as a Vocation. N.Y.: Oxford Univ. Press.

Weber, M., 1978. Economy and Society. Berkeley, L.: Univ. of California Press.

Wendt, A., 2003. Why a World State Is Inevitable. European Journal of International Relations, 9(4), pp. 491-542.

Wolin, S., 2004. Politics and Vision: Continuity and Innovation in Western Political Thought. Princeton, Oxford: Princeton Univ. Press.

Young, L.A. (ed.), 1997. Rational Choice Theory and Religion: Summary and Assessment. New York: Routledge. 